\title{
Effective factors to encourage the foreign direct investment in Iraq
}

\author{
Shahla Mohammad Ali ${ }^{1}$ \\ ${ }^{1}$ Building and Construction Engineering Department, University of Technology, Baghdad, Iraq
}

\begin{abstract}
Foreign direct investment in Iraq cannot take its complete role for different reasons, such as: Lack of security, Corruption, Lack of Transparency, Unequipped banking system, undeveloped arbitration law, Intellectual Property Rights (IPR) issue, and internal disputes over oil rights. It was found that Iraq rates as one of the worst places in the world to do business, languishing at 166 out of 183 countries, according to a World Bank report and for starting a business Iraq ranks even lower
\end{abstract}

\section{Introduction}

Foreign direct investment represents a governing interest in a business enterprise in one country by an entity based on another country.

Foreign direct investment (FDI) is well-known by foreign investment in the portfolio, a negative investment in securities of another country for example equities and public bonds, and the "control" component. Pertaining to the Financial Times, "standard control tariffs adopt a world-wide threshold value of 10 per cent of the voting stock, however this is a gray area where a smaller group of shares will be given control in companies that are exercised on a large scale. Critical inputs can give actual control.

The origin of the investment does not affect the definition as a direct foreign investment, meaning that investment can be "inorganic" by purchasing a company or project in the target country or "organic" throughout the expansion of the operations of an existing company or project in the targeted country.

In general, FDI includes "acquisitions, mergers and acquisitions, the construction of new facilities and the reinvestment of profits from external operations for economic activity and intra-corporate loans."

In a narrow sense, FDI indicates the mere construction of new facilities. It is not possible to compare numerical FDI numbers based on various definitions as a portion of the country's national accounts, and according to GDP equation $\mathrm{Y}=\mathrm{C}+\mathrm{I}+\mathrm{G}+$ (sniff) [i.e. consumption + total investment + government spending + exports and imports]. In addition to domestic investment, a foreign investment can also be considered. FDI is also defined as net investment flows (flow minus flow) for an interest of permanent management, which is greater than or equal to 10 percent voting stock, in an institution that operates in an economy excluding an investor's economy in another country.

Foreign direct investment is the sum of capital (i.e. other long-term capital and short-term capital) as shown in the balance of payments. FDI typically includes the contribution in management, management, joint venture, transmission of experience, technology, and skills. The FDI stock can be considered the net cumulative foreign direct investment (FDI) for any given period of time (i.e., INDI minus). Direct investment does not involve investment through the acquisition of shares. Foreign direct investment can illustrates the movements of international factors [1].

\section{Methodology}

\subsection{Types of FDI}

There are many types of foreign direct investment; the most common are listed below [2]:

1. The emergence of horizontal FDI as the company tries to replicate its country activities at the same step of the value chain in the host country through access to foreign direct investment [3].

2. Foreign direct investment in the platform as foreign direct investment from the exporting country to the targeted country for export to a third country.

3. Vertical FDI occurs once a company's money flows through FDI in the upstream or downstream direction in financially, administratively and organizationally various value chains, i.e. companies carry out value-added activities in a fixed time period in a host country.

\subsection{Importance and difficulties of FDI}

\footnotetext{
* Corresponding author: shahlahikmat@yahoo.com
} 
There has been a fast growth in the population worldwide since 1950 in most developing countries.

This population rise has been met by increases in GDP more rapidly, and therefore each capita income has increased in most countries and throughout many countries since 1950. Whereas the quality of data collected since 1950 is possibly questioned, the average is estimated. Only significant increases in GDP per capita have been recorded in countries ravaged by wars, crises and countries with further serious external challenges such as Haiti, Somalia and the Niger. The data available to check these situations are freely-accessed.

The rise in foreign direct investment could be linked to improve the growth in economy because of capital inflows, increased tax revenues of the host country and the creation of other revenues. Host countries frequently try to guide foreign direct investment to innovative infrastructure projects and other projects to promote economic growth. The competition between new firms can result in a remarkable improvement in both of productivity and efficiency in the host country and the development of competencies. It has been recommended that the adoption of foreign entity policies in a local subsidiary can develop corporate governance standards. Moreover, foreign investment can lead to soft skills' transfer through training and providing job opportunities, the availability of more innovative technology for the domestic market, the transfer of expertise and skills, and access to R \& D resources. [4]

\subsection{Identification of foreign direct investment}

There are large number of theories that try to clarify the determinants of FDI. These theories can be considered essential steps to develop a systematic agenda for the development of FDI. Nevertheless, their respective potential that can be a self-sufficient general theory that could describe and clarify all types of FDI (FDI, domestic, industry and country-level), has been investigated and questioned in the work of various scientists.

Agrawal (1980) [5] could be given as an example. Daning is one of the most reviewers by authors who work on foreign direct investment. Donning (1993) described three major kinds of FDI based on the motive of investment from the viewpoint of an investment firm. The first form of FDI that seeks to achieve the market and presence in it is called concrete, which aims to assist local, regional and global markets. It is also called horizontal FDI, because it comprises duplication of production services in all sectors of the host country.

One type of FDI is investment in foreign direct investment or substitution of exports represents an alternative to FDI. Horizontal FDI offers better service of the local market for goods and services than domestic production, market size and market development of the host economy play many significant roles as difficulties in accessing domestic markets, for instance taxes, duties and transport costs. The second type form of FDI is called for by the search for new resources: when companies invest abroad to acquire resources that are not available and new in the country of origin, like natural resources, raw materials or low-cost labor. Particularly in the manufacturing and extractive sector, when multinational corporations invest directly for export, considerations of factor costs become essential.

Unlike horizontal FDI, vertical or export-oriented FDI is the transfer of parts of the domestic production chain to the host country. The availability of low-cost labor is a major engine of export-oriented FDI. Of course, foreign direct investment in the extractive resource sector, like oil and natural gas, is concerned to countries with abundant natural endowments. The third form of foreign direct investment, which is called the pursuit of efficiency and skills, it occurs when the company can profit from the joint management of geographically spread activities in the existence of economic scale and scope. In 1998, the World Investment Report [4] analyzed the determinants of FDI and the host country's determinants were characterized in the three groups, which are political and economic factors and facilitated business.

\subsection{Prospects for foreign direct investment in Iraq}

Some positive indicators of business chances are [6] - Higher increase in th rate of crude oil revenues: Iraq, according to statistics of the International Monetary Fund and the World Bank, has the growth of gross domestic product by $10 \%$ in 2013 linked to the current paid from the production of crude oil to the current (3) billion barrels per day, including about (2.3) million barrels now, Oil to about (90) dollars a barrel, Iraq's production will be about (100) billion dollars a year of revenue. Iraq is the fourth largest crude oil reserves in the world, and seeks to export (6) million barrels per day by 2017 , according to the special report issued by the International Energy Agency (2012), Iraq could be the second largest source of crude oil globally over the next two decades to ( 2020 ).

- Increased government spending: The growing need for basic services makes government spending high, which is reflected in turn on economic growth, through funding resulting from crude oil revenues, making the need for investment high

- The laws of foreign investment: The issuance of the Investment Law, No. (13) in the year of 2006 and its amendments, gives the right of foreign ownership of companies in all sectors and by $(100 \%)$,excluding the extraction of crude oil and minerals. In this context, the law aims to achieve equality between Iraqi and foreign investors in all forms of trade as a result of reforms. Thus, the investment grew from (3087) billion dollars in 2003 to $(55.67)$ billion dollars in 2011 , i.e. growth by $40.3 \%$ Value Added.

Diversification of the economy: Long sanctions and wars in Iraq have led to a lack of capital, technology and skills for more than two decades, prompting the government to pay attention to investment, especially foreign investment in all sectors of the economy away from oil. The market has been gradually opened to appeal foreign investment and joint ventures in the areas of housing, industry, agriculture, infrastructure, transportation, financial 
services, tourism and others. The government, through the investment law, exempted foreign companies from taxes for a period of ten years and exempted them for three years from import duties.

- Economic Reforms: Iraq's best reform of institutionbuilding for an open economic environment is the conclusion of the agreement in February 2010 with the International Monetary Fund, which embraces a hydrocarbon law with two main objectives:

A) To draw up a new law allowing Iraq to improve its resources.

(B) To draw up a law and regulations for the fair distribution of revenues from crude oil within the country; Although both sides are still in the realm of controversial political negotiations, foreign oil firms have signed contracts all over Iraq, allowing them ("strategic entry") at the moment to ensure a greater market share in the future.

- The opportunity available in the retail sector, which is Iraq's heavy reliance on imports, may increase the chances for investment in the retail sector.

\section{Results and discussion}

\subsection{Difficulties that facing foreign investments in Iraq}

The difficulties and challenges facing foreign investors in business are very large. Iraq is one of the world's worst countries for commercial investment, with 166 out of 183 countries, consistent with the World Bank report. However, this low classification did not prevent foreign companies from working within the Iraqi market despite facing a range of difficulties and challenges, which are as follows:

Security: Although a major problem but the security environment has improved significantly since 2010, Iraq remains one of the world's most dangerous places to invest with the possibility of renewed violence and political instability. However, the security situation in the Kurdistan region of Iraq has been more stable security.

- Financial and administrative corruption: Iraq is ranked as seventh among the most corrupt countries in the world, according to the International Corruption Index (2012) as this is the case for most economies of developing countries. There is a lack of transparency in government laws and regulations and the participation of government officials in bribery, tenders, contracts and embezzlement of public funds. The lack of the judicial system, the public opinion and the media have caused weakness in the face of corruption and allowed the regulatory sector to play its proper role. Corruption is considered one of the most important factors that hinder the growth of the Iraqi business sector according to the classification of the National Institution for Democracy in its report on the survey of businesses in Iraq (2011)

- Lack of transparency: There is an urgent need to develop transparency in order to improve the business environment and investments in Iraq in the field of procurement and procurement procedures and government contracts, since the illegal activity of these procedures may be at a high level, especially in the award of contracts free and open competition. According to the US Business Trade Directory (2012), the Iraqi government's ability to deliver projects is weak and lacks the means to advance technology in that area.

- An inefficient banking system: Reform of the banking system has become imperative for the purpose of attracting foreign investment, although the banking sector has grown rapidly over the past five years due to high oil revenues. (7) banks are state owned and hold $89 \%$ of the country's bank deposits.

The government banks are ineffective and are exposed to bad debts, old losses and the aging of electronic banking systems. In addition to their lack of liquidity, their borrowing rates are low compared to those of the private sector, they suffer from a decrease and a shortage of capital, this is reflected in their activity by borrowing, and these banks require finding equal opportunities for competition as compared to the private sector ones. As government banks rely on Iraqi government spending, restructuring of the organization is more transparent in its policies and financial activities, which may be difficult at all.

Intellectual property rights: Intellectual property rights have specific controls that the Iraqi market lacks control and protection, although the Iraqi government has obliged the adoption of quality control and intellectual property rights on most imported products in July 2011, but counterfeit products in consumer and electronic goods are widely available.

- Arbitration Law: there is lack of arbitration law to settle commercial disputes and lack of commercial arbitration courts in all provinces to settle commercial disputes, which include investors from foreign companies. The Iraqi government is currently drafting a governing law to be entrusted to the United Nations International Trade Law Commission on International Commercial Arbitration.

- Differences of oil rights: One of the issues that affect on the increase in revenues from oil exports is the dispute over the rights of domestic oil and what arose from the dispute over oil rights with the Kurdistan region. The government has finalized the hydrocarbons law and settled disputes with the region, which will provide more clarity to the foreign investor in the oil field; this is the basis for Iraq's economic growth, which requires an investment of $\$ 25$ billion annually to increase its production level.

\section{Conclusions}

Iraq has been assessed as one of the worst places in the world to practice business, languishing at 166 out of 183 countries, consistent with a World Bank report. For starting a business Iraq ranks even lower, at 174. This is due to the following reasons: Lack of security, Corruption, Lack of Transparency, Unequipped banking 
system, undeveloped arbitration law, Intellectual Property Rights (IPR) issue, and internal dispute over oil rights.

\section{References}

1. Wikipedia, (2014).

2. R. Zelot, "FDI effects on developing country economics", FDI journal, 4, (2011).

3. R. S. Saunders, "The Determinants of Foreign Direct Investment." Canadian Journal of Economics, 28, pp. 77-84, (2009).

4. UNCTAD, " World Investment Report, (2010).

5. J. Agarwal, "Determinants of foreign direct investment: A survey", Review of World Economics (Weltwirtschaftliches Archiv), 116 (4), pp. 739-773, 1980.

6. S. A. Cheema ,"Investing in Iraq: Prospects and Challenges", New Delhi India (Feb 20, 2013)

7. J. Parletun, "The Determinants of Foreign Direct Investment: A Regional Analysis with Focus on Belarus",

http://biblioteket.ehl.lu.se/olle/papers/0002948.pdf. 